\title{
Ready-to-eat vegetables production with low-level water chlorination. An evaluation of water quality and of its impact on end products
}

\author{
Francesca D’Acunzo, Angela Del Cimmuto, Lucia Marinelli, \\ Caterina Aurigemma and Maria De Giusti \\ Dipartimento di Sanità Pubblica e Malattie Infettive, Facoltà di Medicina e Chirurgia, \\ Sapienza Università di Roma, Rome, Italy
}

\begin{abstract}
Introduction. We evaluated the microbiological impact of low-level chlorination (1 ppm free chlorine) on the production of ready-to-eat (RTE) vegetables by monitoring the microbiological quality of irrigation and processing water in two production plants over a 4-season period, as well as the microbiological quality of unprocessed vegetables and RTE product. Water samples were also characterized in terms of some chemical and physico-chemical parameters of relevance in chlorination management. Materials and methods. Both producers use water with maximum 1 ppm free chlorine for vegetables rinsing, while the two processes differ by the number of washing cycles. Results and conclusions. Salmonella spp and Campylobacter spp were detected once in two different irrigation water samples out of nine from one producer. No pathogens were found in the vegetable samples. As expected, the procedure encompassing more washing cycles performed slightly better in terms of total mesophilic count (TMC) when comparing unprocessed and RTE vegetables of the same batch. However, data suggest that low-level chlorination may be insufficient in preventing microbial build-up in the washing equipment and/or batch-to batch cross-contamination.
\end{abstract}

Key words: ready-to-eat vegetables, water chlorination, microbiological decontamination.

\begin{abstract}
Riassunto (Produzione di vegetali di IV gamma con acqua clorata a bassa concentrazione. Valutazione della qualità dell'acqua e del suo impatto sul prodotto finito). Introduzione. L'impatto dal punto di vista microbiologico della clorazione a bassa concentrazione (1 ppm cloro libero) nella produzione di vegetali di IV gamma è stato valutato mediante il monitoraggio annuale della qualità microbiologica delle acque di irrigazione e di processo, nonché dei vegetali materia prima e pronti al consumo, presso due impianti di produzione. Sono stati, inoltre, determinati alcuni parametri chimici e chimico-fisici rilevanti nella gestione della clorazione. Materiali e metodi. Entrambi i produttori utilizzano massimo 1 ppm di cloro libero nelle acque di lavaggio. Tuttavia, i processi adottati presso i due stabilimenti differiscono per il numero di cicli di risciacquo. Risultati e conclusioni. Salmonella spp e Campylobacter spp sono stati rinvenuti ciascuno in un campione di acqua di irrigazione su nove, presso uno dei due produttori. Non sono stati rilevati organismi patogeni nei campioni di vegetali. Confrontando i dati di conta mesofila totale di materia prima e prodotto finito dello stesso lotto, il processo comprendente un numero maggiore di cicli di risciacquo fornisce risultati migliori. Tuttavia, i dati ottenuti sembrano indicare che clorazione a bassa concentrazione potrebbe essere insufficiente ai fini della prevenzione della contaminazione delle apparecchiature di lavaggio e della contaminazione crociata tra lotti diversi di vegetali.
\end{abstract}

Parole chiave: vegetali pronti al consumo, clorazione dell'acqua, decontaminazione microbica.

\section{INTRODUCTION}

Ready-to-eat (RTE) vegetables consist of minimally processed produce, conveniently packaged and intended for consumption without further domestic processing (washing and/or cooking). These characteristics of RTE vegetables meet consumers demand for fresh, nutritious food that requires minimal preparation time. As a consequence, the market for such convenient food has been steadily expanding even as overall domestic consumption of fruits and vegetables decreases. For instance, an $8.3 \%$ increase in the consumption of RTE vegetables was observed [1] in Italy between January and October 2010, while, in the same period of time, consumption of fruits and vegetables decreased by $0.8 \%$.

Because RTE vegetables are fresh products with limited shelf-life, that need to be stored under refrigeration, microflora may survive and grow on the product. This issue demands particular attention, since domestic washing and/or cooking, which nor- 
mally take care of microbial contamination of traditional fresh produce, are skipped in the case of RTE vegetables. Pathogen contamination (Salmonella spp, Listeria monocytogenes, E. coli, Campylobacter spp) may occur at any stage in the production process, since it may derive from poor quality of irrigation water, use of manure as fertilizer, or incorrect application of GMP and HACCP during processing. In fact, the presence and prevalence of pathogens in RTE salads [2-6], and the occurrence of epidemic outbreaks related to consumption of contaminated raw vegetables [7-21] are reported in the scientific literature. FAO/WHO Expert Consultation [22] identifies leafy green vegetables as the commodity group of highest concern from a microbiological safety perspective. In 2009, Italy received 98 notifications from European Commission's Rapid Alert System for Food and Feed [23], out of which 74 originated from other EU member States, while all others were issued by the Italian National Alert System. About $10 \%$ of the total alerts involved vegetable products, of which 4 were rocket and mixed salads contaminated with Salmonella spp [24].

Water can have a profound effect on hygiene and safety of the RTE product, since it can be considered as a "raw material" in irrigation, it removes dirt and cell exudates from harvested produce, and reduces the microbial population on the surface of vegetables. Specifically, in RTE vegetables processing, potable water should be used in the final rinsing step [25-28]. The effectiveness and necessity for extensive decontamination is under debate. In fact, shelf-life extension is not necessarily achieved by means of microbial decontamination [29]. Furthermore, decreasing the microbial population may favor the growth of competing pathogens. Current opinion [30] states that adding disinfectant products to water in vegetables processing should not be viewed as a means of sanitizing the product itself. In fact, several literature reports [29, 31-35] show that no advantage derives from adding disinfectants, in terms of total bacterial count after storage of the RTE product. A previous investigation [36] carried out in our laboratory on the microbiological quality of RTE vegetables from industrial plants using different processing strategies showed that focusing on high quality of raw material and process management, rather than counting heavily on sanitizing solutions, results in best end product quality. Adding disinfectants to water should, therefore, be rather viewed as a means of avoiding microbial contamination buildup in the facility, and cross-contamination between batches of processed vegetables. Cross-contamination occurrence in postharvest unit operation is well-documented [4].

Water disinfection through chlorination is a wellestablished, economical and simple way of keeping microbial contamination under control in various circumstances, including processing of RTE vegetables. However, the possibility of development of irritant gaseous chlorine in the working environ- ment, and of formation of chlorinated organic byproducts that may contaminate industrial effluents and RTE products [37] have prompted a number of studies on alternative sanitization methods $[30,32$, 38-46]. Consequently, the use of chlorine is restricted by German law [47].

The efficacy of alternative disinfection methods being under debate, chlorination is still the method of choice, so that control of food quality has to deal with correct chlorination management [48, 49].

Water disinfection is usually carried out by addition of sodium hypochlorite $(\mathrm{NaClO})$ solutions, gaseous chlorine $\left(\mathrm{Cl}_{2}\right)$, or chloride dioxide solutions $(\mathrm{ClO} 2)$. Hypochlorous acid $(\mathrm{HClO})$ resulting from $\mathrm{pH}$-dependent $\mathrm{NaClO}$ hydrolysis or from $\mathrm{Cl}_{2}$ disproportionation (1) is the most effective chlorine species.

$$
\mathrm{Cl}_{2}+\mathrm{H}_{2} \mathrm{O} \rightarrow \mathrm{HOCl}+\mathrm{Cl}^{-}+\mathrm{H}^{+}
$$

Based on reaction (1), addition of basic $\mathrm{NaClO}$ or acidic $\mathrm{Cl}_{2}$ into water should be accompanied with $\mathrm{pH}$ control at 6.5 to 7.5 values, so as to maximize $\mathrm{HOCl}$ concentration and minimize dispersion of $\mathrm{Cl}_{2}$, especially in poor-quality waters with high chloride concentrations. Optimal pH and low chlorides are, therefore, required for best disinfection with "active chlorine". Furthermore, water should be as free as possible from organic matter, which reacts rapidly with $\mathrm{HOCl}$, possibly forming potentially harmful chlorinated organic substances, thus decreasing the amount of chlorine available for disinfection (free chlorine). Other oxidizable inorganic substances, such as ammonia, nitrite, iron and manganese also react with $\mathrm{HOCl}$, [49], so that larger amounts of disinfectants need to be added in order to maintain the desired free chlorine level.

Typical chlorine concentrations in industrial processing of produce range from 50 to $350 \mathrm{ppm}$, depending on the vegetables and on the treatment type [48-50]. Such values are extremely high when compared to those recommended by WHO [51] for potable water, i.e. $0.1-0.3 \mathrm{ppm}$ free chlorine, which is used in domestic processing of vegetables. High chlorine concentrations are justified in industrial vegetables processing by the fact that some microorganisms are poorly sensitive to chlorine. However, some vegetables undergo discoloration when exposed to high concentration chlorine, so that a compromise needs to be found. Furthermore, the effectiveness of sanitizing treatments can be limited towards internalized microorganisms.

In this framework, we report on our experience with two producers that adopt a milder approach for microbial stabilization in the production of RTE vegetables, by maintaining free chlorine in the $0.2-1$ ppm range in processing water

Our study aims at evaluating the impact of lowlevel chlorination on the microbiological quality of water used in industrial vegetables processing for RTE production, and on product decontamination. To this end, the microbiological parameters that 
were monitored in water samples were $\mathrm{TBC}$ at $22^{\circ} \mathrm{C}$; Escherichia coli, Enterococci, Salmonella spp, Listeria monocytogenes and Campylobacter spp, while TMC at $30{ }^{\circ} \mathrm{C}$, Salmonella spp, Listeria monocytogenes, Campylobacter spp and Escherichia coli were determined on vegetable samples. Water samples were also characterized in terms of some physico-chemical parameters and ionic concentrations of relevance in chlorination management

\section{MATERIALS AND METHODS}

Beginning October 2009, a sampling campaign was undertaken at two different RTE vegetables production establishments located in central Italy (Lazio region). The activity of both producers (henceforth producer 1 and 2) encompasses all production steps, from field to RTE product, so that a complete evaluation of the production chain was performed. Each sampling comprised (Figure 1): i) water used for ir-

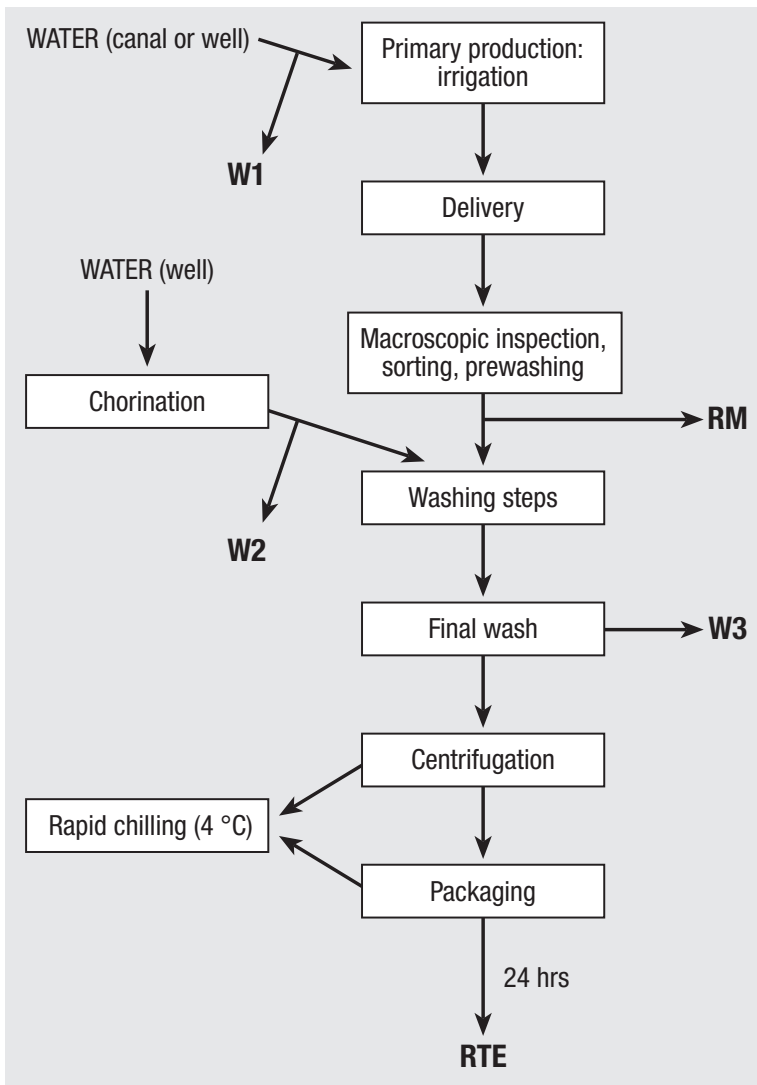

Fig. $1 \mid$ Flow chart describing the main steps in the chain of production of RTE vegetables, and the identification of samples collected for the present study. The number of washing cycles varies between producers. The processing strategy for microbial stabilization may include, as in the case of producer 2, an additional step consisting of rapid chilling of vegetables in a cryogenic tunnel, prior to packaging. W1: irrigation water; W2: chlorinated water entering the processing line; W3: water from the final wash; RM: raw material, i.e. whole vegetables after macroscopic control, sorting, prewashing; RTE: ready-to-eat product 24 hrs after packaging. rigation (W1); ii) potable water entering the processing line (W2); iii) water from the final wash with chlorinated water (W3); iv) unprocessed vegetables ("raw materials") entering the processing line (RM); v) ready-to-eat eat products (RTE). Samples were collected on a monthly basis over a 4-season period, totalling 27 (nine W1, W2, W3) water samples and 18 (nine RM and RTE) vegetable samples from producer 1 and 24 (eight W1, W2, W3) water samples, and 16 (eight RM and RTE) vegetable samples from producer 2 .

\section{Producer 1}

Broad-leaved endive was sampled from producer 1. "Use by" date as established by the producer is 7 days from packaging. Producer 1 utilizes surface water (canal) for irrigation. Processing water is drawn from a well and treated by maintaining $0.2-1 \mathrm{ppm}$ of free chlorine throughout the process. Broad-leaved endive from the field (RM) undergoes a first wash with potable water, and is then transferred via a conveyor belt to a table where it is manually husked. Endive is then cut by an automated cutter under a laminar potable water flow, then transferred to a blowing washer. Contact time of vegetables with rinsing water is five minutes.

\section{Producer 2}

Rocket salad was sampled from producer 2. "Use by" date as established by the producer is 6 days from packaging. Producer 2 utilizes water from a well for irrigation. Processing water used for all washes is drawn from a well and treated, as declared by the producer, by maintaining $0.2-1 \mathrm{ppm}$ of free chlorine. Rocket salad from the field (RM) undergoes a first spray wash on a conveyor belt feeding a blowing washer. Two further washing cycles are performed with closed pipe flumes and blowing washers. Contact time with rinsing water totals about 10 minutes. The product undergoes rapid cooling at $+4{ }^{\circ} \mathrm{C}$ in a nitrogen cooling tunnel (Polar wind tunnel, Turatti, Italy) after centrifugation and before packaging.

\section{Microbiological analysis of water and vegetables}

All samples were transported at $4-6{ }^{\circ} \mathrm{C}$ to the laboratory. Water samples, $\mathrm{RM}$ vegetable samples (48 hours after harvesting), and the RTE vegetable samples (24 hours after packaging) were immediately analyzed.

The following parameters were determined on W1 and W3: TBC at $22^{\circ} \mathrm{C}$; Escherichia coli, Salmonella spp, Listeria monocytogenes and Campylobacter spp.

On W2: TBC at $22^{\circ} \mathrm{C}, E$. coli, enterococci, and pathogens Salmonella spp, L. monocytogenes and Campylobacter spp.

On RM and RTE samples, the following parameters were determined: TMC, E. coli, Salmonella spp, L. monocytogenes, and Campylobacter spp.

All microbiological media were from Oxoid (Cambridge, UK), unless otherwise specified. 
The microbiological determinations on water samples were made using the membrane filtration method for the enumeration of $E$. coli and intestinal enterococci, according to the standard culture method (UNI EN ISO 9308-1/2002; UNI EN ISO 7899-2/2003).

The TBC on water samples was determined using the pour-plate method by inoculation in agar (Plate Count Agar) with a volume of $0.1 \mathrm{~mL}$ and $1 \mathrm{~mL}$ of potable water (W2). Due to heavier contamination of water samples W1 and W3, decimal dilutions were made in BPW (Buffered Peptone Water, Oxoid Cambridge, UK) and analyzed by the same method. Incubation conditions were $22^{\circ} \mathrm{C}$ for $72 \mathrm{~h}$ (UNI EN ISO 6222/2001).

The detection of Salmonella spp, L. monocytogenes and Campylobacter spp was carried out using a modified membrane filtration method: two liters of each water sample were filtered on $0.45 \mu \mathrm{m}$ nitrocellulose membrane filter (Millipore, France), and the residue collected on the membrane was resuspended in $10 \mathrm{~mL}$ of the same water sample; the suspension obtained was shaken vigorously with a Vortex mixer for $3 \mathrm{~min}$ and than $1 \mathrm{~mL}$ was analyzed for detection of pathogens, according to their ISO methods (ISO 6579:2002; ISO 11290-1:1996; ISO 10272-1:2006).

Bacterial determinations on vegetables were carried out using the ISO culture methods for the enumeration of TMC and E. coli (ISO 4833:2003; ISO 16649-2:2001). The appropriate aliquots for analysis were obtained from $750 \mathrm{~g}$ of vegetables (either RM, or five bags of packaged salad) after careful mixing and homogenization.

For detection of pathogens Salmonella spp, L. monocytogenes and Campylobacter spp, twenty five grams of each sample were analyzed according to ISO culture methods (ISO 10272-1:2006, ISO 6579:2002 and ISO 11290-1:1996, respectively).

Salmonella spp and L. monocytogenes were also detected by PCR Bax System (DuPont-Qualicon, Geneva, Switzerland), a rapid molecular method that uses PCR technology for screening of pathogens in food and environmental samples, according to the manufacturer's instructions.

\section{Chemical analysis of water}

$\mathrm{pH}$, conductivity, ammonium, nitrates and nitrites in water were determined upon arrival of the samples in the laboratory. $100 \mathrm{~mL}$ of each sample were transferred in PE bottles (Nalgene Labware, Thermofisher Scientific, USA), $1 \mathrm{~mL}$ of trace metal analysis grade nitric acid (Romil, Cambridge, UK) was added, and the resulting solutions were stored at $4{ }^{\circ} \mathrm{C}$ until metal analysis by Flame Atomic Absorption Spectrophotometry was carried out within one month from sampling.

pH (Hanna Instruments 8314 pH-meter) was determined after calibration with standards (Merck, Germany) at pH 4.0, 7.0, and 10.0.

Conductivity was measured with a conductivimeter (Hanna Instruments 8733) calibrated with a standard (Hanna Instruments, Italy) at $12880 \mu \mathrm{S} / \mathrm{cm}$ at $25^{\circ} \mathrm{C}$.
Spectrophotometrical assays were performed on a Beckman Coulter DU530 spectrophotometer. All solutions were prepared with distilled deionized water at $18.2 \mathrm{M} \Omega / \mathrm{cm}$ (Sartorius Stedim arium $611 \mathrm{VF}$ ). All reagents were analytical grade and, unless otherwise specified, purchased from Carlo Erba (Italy), Merck (Germany), or Alfa Aesar (Germany). The following methods are adapted from Standard methods for the examination of water and wastewater [52].

Ammonia was determined by the phenate method after distillation in a Kjeldhal apparatus. Quantitation was performed against a standard solution at $0.2 \mathrm{mg} /$ $\mathrm{L}$, obtained by dilution of a certified $1000 \mathrm{mg} / \mathrm{L}$ ammonium standard (Merck, Germany).

Nitrites were determined by means of the Griess reaction. Quantitation was performed against a standard solution at $1 \mathrm{mg} / \mathrm{L}$, obtained by dilution of a certified $1000 \mathrm{mg} / \mathrm{L}$ nitrite standard (Merck, Germany).

Nitrates were determined after reduction to nitrites with $5 \% \mathrm{Cd}(\mathrm{OAc}) 2,2 \mathrm{~mL}$ concentrated $\mathrm{NH} 3$, and 0.5 $\mathrm{g}$ powdered $\mathrm{Zn}$. The resulting nitrites are determined with the Griess reaction.

Chlorides were determined by Mohr's argentometric method, i.e. by direct titration with $0.01 \mathrm{~N}$ silver nitrate standard solution (Panreac Quimica, Spain) at $\mathrm{pH} 7-10\left(\mathrm{H}_{2} \mathrm{SO}_{4}\right.$ or $\mathrm{NaOH}$ can be used to adjust $\mathrm{pH}$ when necessary), in the presence of potassium chromate as indicator. Possible interference by sulphides was eliminated by treatment with hydrogen peroxide.

Fixed residue was determined by evaporating 100 $\mathrm{mL}$ water in a Teflon PFA capsule (Nalgene Labware, Thermofisher Scientific, USA), in a muffle furnace at $180{ }^{\circ} \mathrm{C}$ to constant weight.

Metals ( $\mathrm{Na}, \mathrm{K}, \mathrm{Ca}, \mathrm{Mg}, \mathrm{Mn}, \mathrm{Fe}$ ) were determined by direct aspiration of the acidified water sample into the air-acetilene flame of a AAS (Perkin Elmer 4100 interfaced with Windows NT workstation equipped with AA Winlab Analysis software). The calibration curve was constructed prior to each analysis by means of standard solutions obtained by diluting $1000 \mathrm{mg} / \mathrm{L}$ commercial standard solutions (Merck, Germany).

\section{RESULTS \\ Microbiological quality of water, raw materials, and RTE products}

Microbiological data in Tables 1 and 2 show that TBC ranges of W1 and of W2 are low. Some differences should be pointed out between canal water W1 from producer 1, and W1 from producer 2's well. In fact, the former exhibits a higher TBC than the latter, in association with presence of regulated microorganisms that, in some cases, are more numerous than established by the limits set by Italian law $[53,54]$ for treated wastewater used for irrigation: Escherichia coli higher than 100 $\mathrm{cfu} / 100 \mathrm{~mL}$ in four samples out of nine (point values: 500, 538, 138, $1700 \mathrm{cfu} / 100 \mathrm{~mL}$ ); Salmonella spp and Campylobacter spp which should be absent, are found in two different samples. It is worth noting that no pathogens or $E$. coli are found in W3, RM, and RTE 
Table $1 \mid$ Results of the microbiological analyses of W1,W2, W3 water samples and RM and RTE vegetable samples from producer 1

\begin{tabular}{|c|c|c|c|c|c|}
\hline \multirow[b]{2}{*}{$\begin{array}{l}\text { Parameter } \\
\text { (units) }\end{array}$} & \multicolumn{5}{|c|}{ Producer 1} \\
\hline & $\begin{array}{c}\text { W1 } \\
\text { Average } \\
\text { [range] }\end{array}$ & $\begin{array}{c}\text { W2 } \\
\text { Average } \\
\text { [range] }\end{array}$ & $\begin{array}{c}\text { W3 } \\
\text { Average } \\
\text { [range] }\end{array}$ & $\begin{array}{c}\text { RM } \\
\text { Average } \\
\text { [range] }\end{array}$ & $\begin{array}{c}\text { RTE } \\
\text { Average } \\
\text { [range] }\end{array}$ \\
\hline $\begin{array}{l}\mathrm{TBC} \text { at } 22^{\circ} \mathrm{C} \\
\text { (cfu/ml) }\end{array}$ & $\begin{array}{c}5.5 \times 10^{4} \\
{\left[5.0 \times 10^{1}-3.4 \times 10^{5}\right]}\end{array}$ & $\begin{array}{c}3.0 \times 10^{1} \\
{\left[0.0-1.7 \times 10^{2}\right]}\end{array}$ & $\begin{array}{l}3.3 \times 10^{4} \\
{\left[2.6-2.0 \times 10^{5}\right]}\end{array}$ & n.d. & n.d. \\
\hline $\begin{array}{l}\mathrm{TMC} \text { at } 30^{\circ} \mathrm{C} \\
\text { (cfu/g) }\end{array}$ & n.d. & n.d. & n.d. & $\begin{array}{c}2.1 \times 10^{9} \\
{\left[2.1 \times 10^{5}-1.8 \times 10^{10}\right]}\end{array}$ & $\begin{array}{c}9.9 \times 10^{8} \\
{\left[7.5 \times 0^{4}-8.9 \times 10^{9}\right]}\end{array}$ \\
\hline $\begin{array}{l}\text { Escherichia coli } \\
\text { (cfu/100 mL - cfu/g) }\end{array}$ & $\begin{array}{c}3.4 \times 10^{2} \\
{\left[0.0-1.7 \times 10^{3}\right]}\end{array}$ & $<1$ & $<1$ & $<10$ & $<10$ \\
\hline $\begin{array}{l}\text { Enterococci } \\
\text { (cfu/100 mL) }\end{array}$ & n.d. & $<1$ & n.d. & n.d. & n.d. \\
\hline $\begin{array}{l}\text { Salmonella spp } \\
\text { (Presence/Absence in } 2 \mathrm{~L} \text { or } 25 \mathrm{~g} \text { ) }\end{array}$ & Pres $^{(a)}$ & Abs & Abs & Abs & Abs \\
\hline $\begin{array}{l}\text { L. monocytogenes } \\
\text { (Presence/Absence in } 2 \mathrm{~L} \text { or } 25 \mathrm{~g} \text { ) }\end{array}$ & Abs & Abs & Abs & Abs & Abs \\
\hline $\begin{array}{l}\text { Campylobacter spp } \\
\text { (Presence/Absence in } 2 \mathrm{~L} \text { or } 25 \mathrm{~g} \text { ) }\end{array}$ & $\operatorname{Pres}^{(b)}$ & Abs & Abs & Abs & Abs \\
\hline
\end{tabular}

from producer 1 , so that contamination of $\mathrm{W} 1$ within the ranges in Table 1 does not seem to be carried over to the vegetables and to the processing water. No pathogens are found in W1 from producer 2. TBC is higher in W3 than in W2 at both producers. This may be attributed to microbial contribution from the vegetables being processed, to microbial build-up in the washing equipment, or to cross-contamination between batches. Data on microbial load differences between RM and RTE of the same batches (Figure 2) show a great variability at producer 1 , where, in some cases, a reduction in the order of 3-4 log units was achieved, while on two occasions was the TMC higher in the RTE than in the RM samples. These data point at microbial build-up and/or cross contamination. As for producer 2, the microbial load in the RTE was always found comparable to or lower than the RM (less than 2 log units reduction at best, however). Therefore, a process encompassing multiple rinsing steps appears to be more reproducible in time. However, there is a possibility that microbial build-up and cross contamination may be liable for the limited reduction at producer 2 .

Overall, when it comes to evaluating the impact of the procedures adopted by the two producers on the microbiological quality of the RTE, the outcome is quite similar. In fact (Tables 1 and 2), the TMCs of RMs and of RTE products from both producers are in the same order of magnitude.

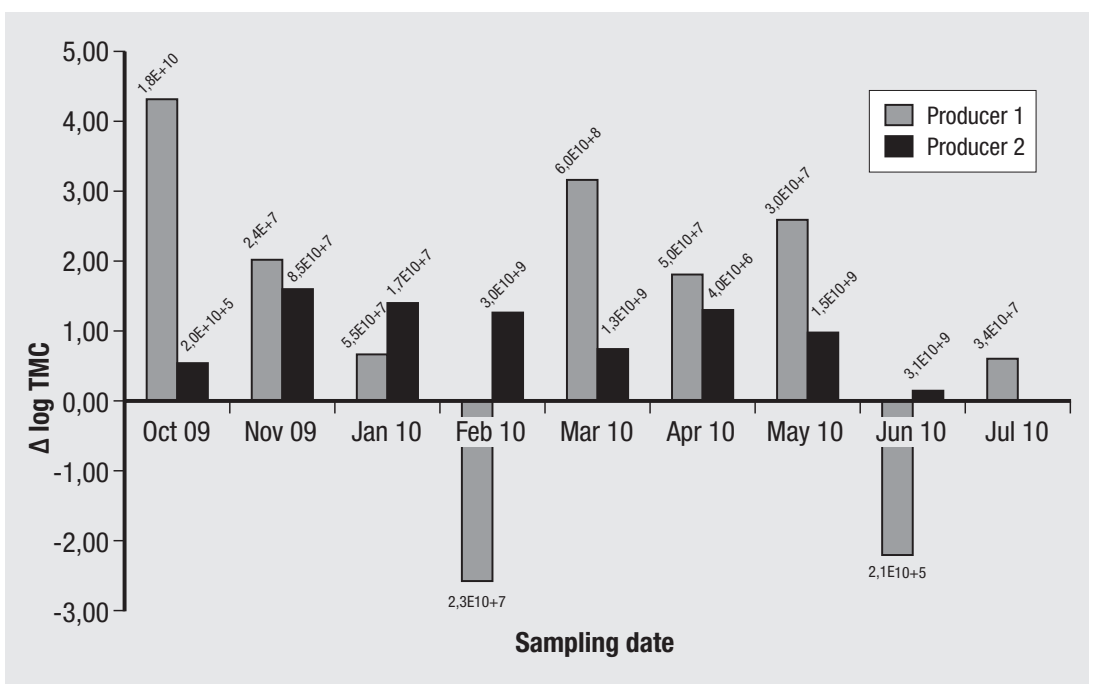

Fig. $2 \mid$ Microbial load reduction in $\log$ units (log TMC of raw material - $\log$ TMC of RTE vegetable) at producer 1 (light bars) and producer 2 (dark bars). The labels on the bars of the histograms are the TMCs of the RMS. 


\begin{tabular}{|c|c|c|c|c|c|}
\hline \multirow[b]{2}{*}{$\begin{array}{l}\text { Parameter } \\
\text { (units) }\end{array}$} & \multicolumn{5}{|c|}{ Producer 2} \\
\hline & $\begin{array}{c}\text { W1 } \\
\text { Average } \\
\text { [range] }\end{array}$ & $\begin{array}{c}\text { W2 } \\
\text { Average } \\
\text { [range] }\end{array}$ & $\begin{array}{c}\text { W3 } \\
\text { Average } \\
\text { [range] }\end{array}$ & $\begin{array}{c}\text { RM } \\
\text { Average } \\
\text { [range] }\end{array}$ & $\begin{array}{c}\text { RTE } \\
\text { Average } \\
\text { [range] }\end{array}$ \\
\hline $\begin{array}{l}\mathrm{TBC} \text { a } 22{ }^{\circ} \mathrm{C} \\
\text { (cfu/ml) }\end{array}$ & $\begin{array}{c}2.1 \times 10^{2} \\
{\left[0.0-1.6 \times 10^{3}\right]}\end{array}$ & $\begin{array}{c}6.0 \\
{\left[0.0-1.9 \times 10^{1}\right]}\end{array}$ & $\begin{array}{c}3.8 \times 10^{6} \\
{\left[0.0-3.0 \times 10^{7}\right]}\end{array}$ & n.d. & n.d. \\
\hline $\begin{array}{l}\mathrm{TMC} \text { a } 30^{\circ} \mathrm{C} \\
\text { (cfu/g) }\end{array}$ & n.d. & n.d. & n.d. & $\begin{array}{c}4.3 \times 10^{8} \\
{\left[2.0 \times 105-3.0 \times 10^{9}\right]}\end{array}$ & $\begin{array}{c}2.8 \times 10^{8} \\
{\left[5.3 \times 104-2.1 \times 10^{9}\right]}\end{array}$ \\
\hline $\begin{array}{l}\text { Escherichia coli } \\
\text { (cfu/100 mL - ufc/g) }\end{array}$ & $<1$ & $<1$ & $<1$ & $<10$ & $<10$ \\
\hline $\begin{array}{l}\text { Enterococci } \\
\text { (cfu/100 mL) }\end{array}$ & n.d. & $<1$ & n.d. & n.d. & n.d. \\
\hline $\begin{array}{l}\text { Salmonella spp } \\
\text { (Presence/Absence in } 2 \mathrm{~L} \text { or } 25 \mathrm{~g} \text { ) }\end{array}$ & Abs & Abs & Abs & Abs & Abs \\
\hline $\begin{array}{l}\text { L. monocytogenes } \\
\text { (Presence/Absence in } 2 \mathrm{~L} \text { or } 25 \mathrm{~g} \text { ) }\end{array}$ & Abs & Abs & Abs & Abs & Abs \\
\hline $\begin{array}{l}\text { Campylobacter spp } \\
\text { (Presence/Absence in } 2 \mathrm{~L} \text { or } 25 \mathrm{~g} \text { ) }\end{array}$ & Abs & Abs & Abs & Abs & Abs \\
\hline
\end{tabular}

Table $3 \mid$ Averages and ranges of the results of the physico-chemical analyses of $W 1, W 2$, and $W 3$ water samples from producer 1 and producer 2

\section{Producer 1}

\begin{tabular}{|c|c|c|c|c|c|c|}
\hline Average [range] & W1 & W2 & W3 & W1 & W2 & W3 \\
\hline $\mathrm{pH}$ & $\begin{array}{c}7.15 \\
{[6.93-7.5]}\end{array}$ & $\begin{array}{c}6.95 \\
{[6.78-7.02]}\end{array}$ & $\begin{array}{c}6.96 \\
{[6.50-6.96]}\end{array}$ & $\begin{array}{c}7.05 \\
{[6.87-7.29]}\end{array}$ & $\begin{array}{c}7.14 \\
{[7.00-7.14]}\end{array}$ & $\begin{array}{c}7.41 \\
{[7.00-7.85]}\end{array}$ \\
\hline $\begin{array}{l}\text { Conductivity } \\
(\mu \mathrm{S} / \mathrm{cm})\end{array}$ & $\begin{array}{c}1047 \\
{[489-1802]}\end{array}$ & $\begin{array}{c}1215 \\
{[700-2070]}\end{array}$ & $\begin{array}{c}1335 \\
{[593-2080]}\end{array}$ & $\begin{array}{c}397 \\
{[295-483]}\end{array}$ & $\begin{array}{c}1388 \\
{[694-2100]}\end{array}$ & $\begin{array}{c}1640 \\
{[760-2130]}\end{array}$ \\
\hline $\begin{array}{l}\text { Fixed residue at } 180^{\circ} \mathrm{C} \\
(\mathrm{mg} / \mathrm{L})\end{array}$ & $\begin{array}{c}915 \\
{[572-1892]}\end{array}$ & $\begin{array}{c}806 \\
{[368-1600]}\end{array}$ & $\begin{array}{c}918 \\
{[762-1457]}\end{array}$ & $\begin{array}{c}162 \\
{[82-227]}\end{array}$ & $\begin{array}{c}849 \\
{[127-1182]}\end{array}$ & $\begin{array}{c}941 \\
{[666-1077]}\end{array}$ \\
\hline $\begin{array}{l}N(\text { Ammonium) })^{(1)} \\
(\mathrm{mg} / \mathrm{L})\end{array}$ & $\begin{array}{c}0.21 \\
{[0.01-0.94]}\end{array}$ & $\begin{array}{c}0.08 \\
{[0.04-0.14]}\end{array}$ & $\begin{array}{c}0.12 \\
{[0.05-0.20]}\end{array}$ & $\begin{array}{c}0.02 \\
{[0.01-0.04]}\end{array}$ & $\begin{array}{c}0.15 \\
{[0.01-0.59]}\end{array}$ & $\begin{array}{c}0.16 \\
{[0.02-0.70]}\end{array}$ \\
\hline $\begin{array}{l}\mathrm{N} \text { (Nitrate)(1) } \\
\text { (mg/L) }^{(1)}\end{array}$ & $\begin{array}{c}1.53 \\
{[0.05-4.3]}\end{array}$ & $\begin{array}{c}0.10 \\
{[<0.01-0.16]}\end{array}$ & $\begin{array}{c}1.38 \\
{[<0.01-2.71]}\end{array}$ & $\begin{array}{c}5.52 \\
{[3.50-6.50]}\end{array}$ & $\begin{array}{c}0.94 \\
{[0.25-1.44]}\end{array}$ & $\begin{array}{c}0.71 \\
{[0.40-1.25]}\end{array}$ \\
\hline $\begin{array}{l}\text { N (Nitrite)(1) } \\
\text { (mg/L) }\end{array}$ & {$\left[\begin{array}{c}0.02 \\
{[<0.01-0.04]}\end{array}\right.$} & $\begin{array}{c}0.01 \\
{[<0.01-0.01]}\end{array}$ & $\begin{array}{c}0.01 \\
{[<0.01-0.01]}\end{array}$ & $<0.01$ & $<0.01$ & $<0.01$ \\
\hline $\begin{array}{l}\text { Chloride } \\
\text { (mg/L) }\end{array}$ & $\begin{array}{c}211.2 \\
{[40.8-398.1]}\end{array}$ & $\begin{array}{c}262.8 \\
{[85.4-500.6]}\end{array}$ & $\begin{array}{c}266.5 \\
{[83.3-496.3]}\end{array}$ & $\begin{array}{c}50.2 \\
{[17.5-73.4]}\end{array}$ & $\begin{array}{c}557.2 \\
{[170.16-961.0]}\end{array}$ & $\begin{array}{c}487.3 \\
{[226.2-858]}\end{array}$ \\
\hline $\begin{array}{l}\text { Sodium } \\
\text { (mg/L) }\end{array}$ & $\begin{array}{c}111.2 \\
{[67.0-219.7]}\end{array}$ & $\begin{array}{c}135.5 \\
{[55.0-245]}\end{array}$ & $\begin{array}{c}121.9 \\
{[56.0-239]}\end{array}$ & $\begin{array}{c}9.4 \\
{[7.1-17.7]}\end{array}$ & $\begin{array}{c}192.9 \\
{[148-242]}\end{array}$ & $\begin{array}{c}216.3 \\
{[132-267]}\end{array}$ \\
\hline $\begin{array}{l}\text { Potassium } \\
\text { (mg/L) }\end{array}$ & $\begin{array}{c}17.4 \\
{[8.0-27.2]}\end{array}$ & $\begin{array}{c}15.5 \\
{[12.2-21.3]}\end{array}$ & $\begin{array}{c}17.5 \\
{[13.1-21.7]}\end{array}$ & $\begin{array}{c}5.0 \\
{[4.0-7.1]}\end{array}$ & $\begin{array}{c}28.1 \\
{[24.1-30.2]}\end{array}$ & $\begin{array}{c}29.1 \\
{[26.6-32.5]}\end{array}$ \\
\hline $\begin{array}{l}\text { Iron } \\
\text { (mg/L) }\end{array}$ & $\begin{array}{c}0.24 \\
{[0.08-0.46]}\end{array}$ & $\begin{array}{c}0.22 \\
{[0.07-0.41]}\end{array}$ & $\begin{array}{c}0.23 \\
{[0.07-0.61]}\end{array}$ & $\begin{array}{c}0.13 \\
{[<0.02-0.48]}\end{array}$ & $\begin{array}{c}0.19 \\
{[0.02-0.56]}\end{array}$ & $\begin{array}{c}0.12 \\
{[0.03-0.20]}\end{array}$ \\
\hline $\begin{array}{l}\text { Manganese } \\
\text { (mg/L) }\end{array}$ & $\begin{array}{c}0.05 \\
{[0.01-0.15]}\end{array}$ & $\begin{array}{c}0.04 \\
{[0.01-0.15]}\end{array}$ & $\begin{array}{c}0.03 \\
{[0.01-0.04]}\end{array}$ & $\begin{array}{c}0.01 \\
{[<0.02-0.06]}\end{array}$ & $\begin{array}{c}0.20 \\
{[<0.02-1.45]}\end{array}$ & $\begin{array}{c}0.19 \\
{[<0.02-1.42]}\end{array}$ \\
\hline
\end{tabular}



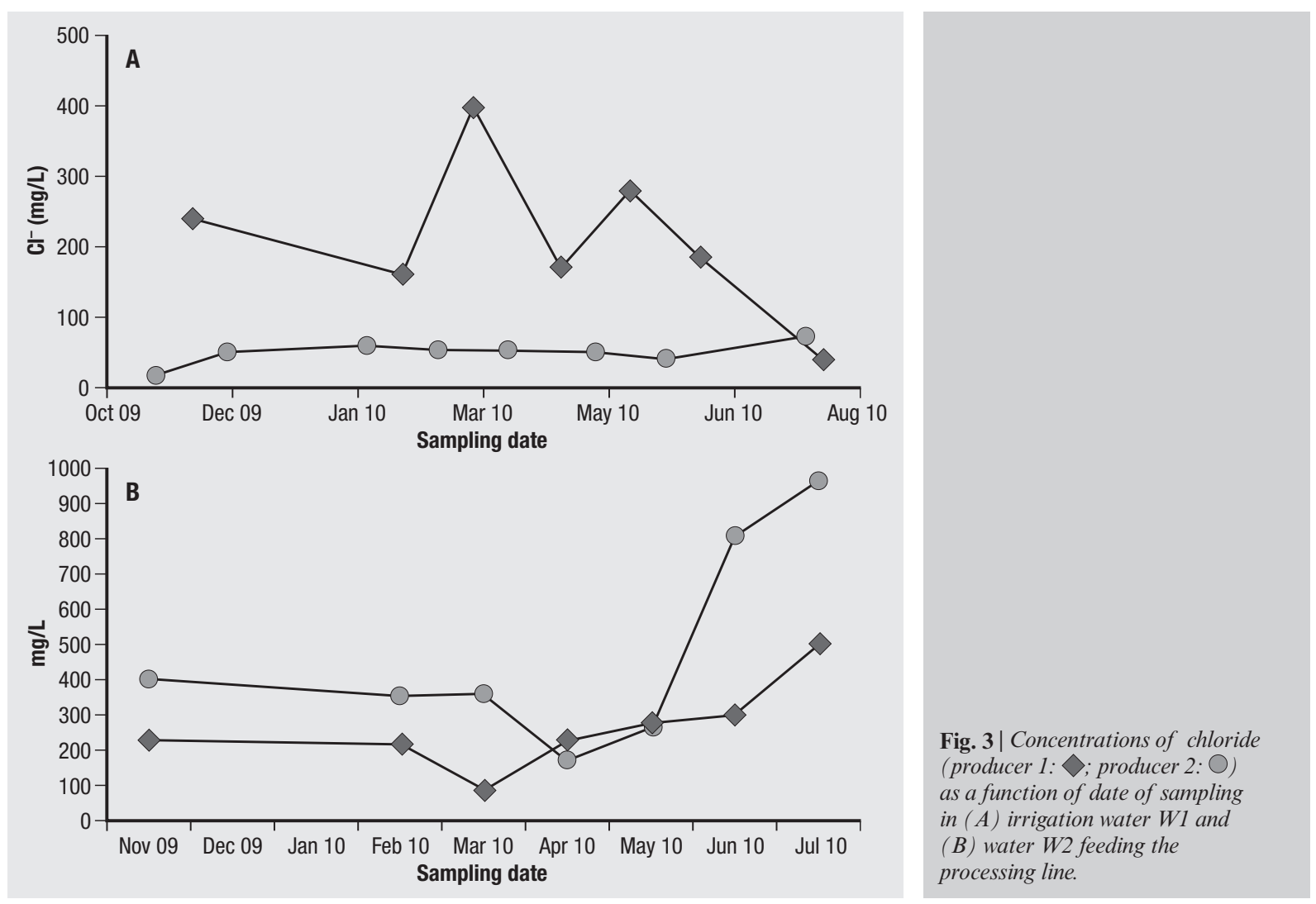

\section{Chemical characterization of irrigation and rinsing water}

Table 3 summarizes averages and ranges of the results of the physico-chemical analyses of W1, W2, and $\mathrm{W} 3$ from both producers. The average chloride concentration in canal water W1 from producer 1 is higher than in W1 from producer 2's well. In fact, chloride concentrations (Figure 3a) in canal W1 from producer 1 are higher than the $250 \mathrm{mg} / \mathrm{L}$ limit Legislative Decree 152/2006. [53] in two out of seven determinations, with one value as high as $398 \mathrm{mg} / \mathrm{L}$, while in $\mathrm{W} 1$ from producer 2 (well), chloride concentrations are less variable, and well below $250 \mathrm{mg} / \mathrm{L}$. Nitrogen in the nitrite and nitrate forms (Table 3 ) in W1 from both producers are well below the limits set for potable water [55] of $0.5 \mathrm{mg} / \mathrm{L}$ and $50 \mathrm{mg} / \mathrm{L}$, respectively. Fixed residue is higher in producer 1's W1 (canal water), than in W1 from producer 2's well.

As for W2 water samples, the outcomes of the chemical analyses (Table 3) are similar among the two producers, with small differences in $\mathrm{pH}$ (slightly more acidic at producer 1 than at producer 2) and ammonium. Chloride concentrations are consistently lower in W2 from producer 1 than from producer 2. In fact, all but one chloride concentration values in W2 from producer 2 are higher than 250 $\mathrm{mg} / \mathrm{L}$, i.e. the limit value for potable water [54], with a steep and continuous increase between April and July (Figure $3 b$ ).

A comparison between microbial load reduction at producer 2 (Figure 2) and chloride concentration trend in W2 from the same producer (Figure 3) does not provide any evidence for correlating disinfection efficacy and chloride concentration [48, 49].

No difference is worth noting between W2 and W3 with respect to the physico-chemical parameters determined (Table 3). In fact, W3 consists merely of $\mathrm{W} 2$ that has come into contact with the produce in the washing tanks, so that no difference was expected between these samples. Other chemical parameters may be considered (i.e. pesticides, fertilizers, disinfection by-products), the analysis of which is beyond the scope of this study, and deserves further investigation.

\section{DISCUSSION}

The frame of reference provided by current legislation and codes of practice for evaluating the quality of irrigation water is quite poor. Current Italian legislation $[53,54]$ focuses on the need for optimizing resources by utilizing, for irrigation purposes, treated wastewater, thus setting a mere "worst case scenario" with respect to water quality standards. It is worth noting that the chemical characteristics of water in the area where both producers are located is influenced by several factors, i.e. proximity to the marine coast, presence of underground thermal water, and seasonal trends in rainwater contribution (dry Spring-Summer season). The main chemical parameter that reflects such peculiarities is chloride concentration, which is considered of relevance to chlorination efficacy. 
Chloride concentration in irrigation water from producer 2 (drawn from a well) was below the limits, and its microbiological quality was also good. Notwithstanding the differences in the quality of irrigation water between the two producers, pathogens were absent in the RMs from both, and TMCs were in the same range.

As for the different industrial procedures adopted by the two producers, the overall outcome is quite similar in terms of TMC. In fact, TMC ranges of RMs and of RTE products from both producers are in the same order of magnitude. No conclusions can be drawn on pathogens, since they were absent in all vegetable samples (raw material and RTE), as well as in all processing water samples. However, when looking closer at the production flow, rather than at overall performances, two observations can be made. First of all, microbial load reduction in the vegetables is not reproducible from batch to batch with the minimal process, while a more reproducible reduction is observed with the multiple washing process. Furthermore, there is some indication of microbial build-up in the washing apparatus and/or cross-contamination between batches, particularly at the producer adopting the minimal process. In

\section{References}

1. Italy. Istituto di Servizi per il Mercato Agricolo Alimentare (ISMEA). Le tendenze degli acquisti domestici agroalimentari. [Trends in produce market for domestic consumption]. n. 2/10 October 2010 .

2. Beuchat LR. Listeria monocytogenes: incidence on vegetables. Food Control 1996; 7:223-8.

http://dx.doi.org/10.1016/S0956-7135(96)00039-4

3. de Curtis ML, Franceschi O, De Castro N. Listeria monocytogenes in vegetables minimally processed. Arch Latinoam Nutr 2002;52:282-8.

4. Doyle MP, Erickson MC. Summer meeting 2007 - the problems wih fresh produce: an overview. J Appl Microbiol 2008;105:317-30. http://dx.doi.org/10.1111/j.1365-2672.2008.03746.x

5. Fröder H, Martins CG, De Souza KL, Landgraf M, Franco BD, Destro M T. Minimally processed vegetable salads: microbial quality evaluation. J Food Prot 2007;70:1277-80.

6. Little CL, Taylor FC, Sagoo SK, Gillespie IA, Grant K, McLauchlin J. Prevalence and level of Listeria monocytogenes and other Listeria species in retail pre-packaged mixed vegetable salads in the UK. Food Microbiol 2007;24:711-7. http://dx.doi.org/10.1016/j.fm.2007.03.009

7. Ackers ML, Mahon B E, Leahy E, Goode B, Damrow T, Hayes PS, Bibb WF, Rice DH, Barett TJ, Hutwager L, Griffin PM, Slutsker L. An outbreak of Escherichia coli O157:H7 infections associated with leaf lettuce consumption. J Infect Dis 1998; 177:1588-93 http://dx.doi.org/10.1086/515323

8. Crook PD, Aguilera J F, Threlfall EJ, O'Brien SJ, Sigmundsdottir G, Wilson D, Fisher IS, Ammon A, Briem H, Cowden JM, Locking ME, Tschape H, van Pelt W, Ward LR, Widdowson MA. A European outbreak of Salmonella enterica serotype Typhimurium definitive phage type 204b in. Clin Microbiol Infect 2000;9:839-45. http://dx.doi.org/10.1046/j.1469-0691.2003.00655.x

9. Dentinger CM, Bower WA, Nainan OV, Cotter SM, Myers G, Dubusky LM, Fowler S, Salehi ED, Bell BP. An outbreak of hepatitis A associated with green onions. J Infect Dis 2001; 183:1273-6

http://dx.doi.org/10.1086/319688 conclusion, if we take TMC reduction as an indicator of the efficacy of the process, water chlorination at a low level $(0.2-1 \mathrm{ppm})$ is adequate for RTE vegetables production, provided that the industrial process encompasses a sufficient number of washing cycles, with a sufficiently long contact times with chlorinated water. Furthermore, periodical sanitization of the washing apparatus is advisable in order to contrast microbial build-up and cross-contamination between batches. As for those chemical parameters that may be relevant for disinfection efficacy, both processes appeared insensitive to variations in chloride concentration.

\section{Acknowledgements}

We wish to thank Emidio Testa for his help in interacting with RTE vegetables producers.

We also thank Matteo Vitali for useful discussion on chemical data interpretation.

\section{Conflict of interest statement}

Authors report no financial relationships with commercial interests.

Received on 21 November 2011.

Accepted on 12 March 2012.

10. Europe. Scientific Committee on Food (EU). Risk profile on the microbiological contamination of fruits and vegetables eaten raw. 2002. Avalaible from: http://ec.europa.eu/food/fs/ sc/scf/out125_en.pdf.

11. Grotto I, Huerta M, Balicer RD, Halperin T, Cohen D, Orr $\mathrm{N}$, Gdalevich M. An outbreak of norovirus gastroenteritis on an Israeli military base. Infection 2004;32:339-43. http://dx.doi.org/10.1007/s15010-004-4002-3

12. Gupta SK, Nalluswami K, Snider C, Perch M, Balasegaram M, Burmeister D, Lockett J, Sandt C, Hoekstra RM, Montgomery S. Outbreak of Salmonella Braenderup infections associated with Roma tomatoes, northeastern United States, 2004: a useful method for subtyping exposures in field investigations. Epidemiol Infect 2007;135:1165-73. http://dx.doi.org/10.1017/S0950268807007911

13. Hanning IB, Nutt JD, Ricke SC. Salmonellosis outbreaks in the United States due to fresh produce: sources and potential intervention measures. Foodborne Pathog Dis 2009;6:635-48. http://dx.doi.org/10.1089/fpd.2008.0232

14. Hilborn ED, Mermin JH, Mshar PA, Hadler JL, Voetsch A, Wojtkunski C, Swartz M, Mshar R, Lambert-Fair MA, Farrar JA, Glynn MK, Slutsker L. A multistate outbreak of Escherichia coli O157:H7 infections associated with consumption of mesclun lettuce. Arch Intern Med 1999;159:1758-64. http://dx.doi.org/10.1001/archinte.159.15.1758

15. Horby PW, O’Brien SJ, Adak GK, Graham C, Hawker JI, Hunter P, Lane C, Lawson AJ, Mitchell RT, Reacher MH, Threlfall EJ, Ward LR. A national outbreak of multi-resistant Salmonella enterica serovar Typhimurium definitive phage type (DT) 104 associated with consumption of lettuce. Epidemiol Infect 2003;130:169-78. http://dx.doi.org/10.1017/S0950268802008063

16. Nygård K, Lassen J, Vold L, Andersson Y, Fisher I, Löfdahl S, Threlfall J, Luzzi I, Peters T, Hampton M, Torpdahl M, Kapperud G, Aavitsland P. Outbreak of Salmonella Thompson infections linked to imported rucola lettuce. Foodborne Pathog Dis 2008;5:165-73. http://dx.doi.org/10.1089/fpd.2007.0053

17. Rosenblum LS, Mirkin IR, Allen DT, Safford S, Hadler SC. 
A multifocal outbreak of hepatitis A traced to commercially distributed lettuce. Am J Public Health 1990;80:1075-9. http://dx.doi.org/10.2105/AJPH.80.9.1075

18. Sagoo SK, Little CL, Ward L, Gillespie IA, Mitchell RT. Microbiological study of RTE salad vegetables from retail establishments uncovers a national outbreak of salmonellosis. J Food Prot 2003;66:403-9.

19. Soderstrom A, Osterberg P, Lindqvist A, Jonsson B, Lindberg A, Blide S, Ulander C, Welinder-Olsson S, Lofdahl B, Kaijser B, De Jong S, Kuhlmann-Berenzon S, Boqvist E, Eriksson E, Szanto S, Andersson G, Allestam I, Hedenstrom L, Muller L, Andersson Y. A large Escherichia coli O157 outbreak in Sweden associated with locally produced lettuce. Foodborne Pathog Dis 2008;5:339-49.

http://dx.doi.org/10.1089/fpd.2007.0065

20. Ward LR, Maguire C, Hampton MD, de Pinna E, Smith HR, Little CL, Gillespie IA, O'Brien SJ, Mitchell RT, Sharp C, Swann RA, Doyle O, Threlfall EJ. Collaborative investigation of an outbreak of Salmonella enterica serotype Newport in England and Wales in 2001 associated with RTE salad vegetables. Commun Dis Public Health 2002;5:301-4.

21. Wells JM, Butterfield JE. Salmonella contamination associated with bacterial soft rot of fresh fruits and vegetables in the marketplace. Plant Dis 1997;81:867-72.

22. Food and Agricolture Organization of United Nations (FAO) and World Health Organization (WHO). Microbiological hazards in fresh fruits and vegetables - Meeting Report. Microbiological Risk Assessment Series. 2008.

23. Europe. RASFF Rapid Alert System for Food and Feed (Technical report 2009). Available from: http://ec.europa.eu/ food/food/rapidalert/docs/report2009_en.pdf. http://dx.doi.org/10.2772/88477

24. Toti L, Durante G, Piccotto L, Deliberato E, Di Pasquale S, De Medici D, Capuano F, Caligiuri V, Mioni R, Mancini L, Scenati R, Marcheggiani S, De Giusti M, Luzzi I. Microbiological aspects in vegetables food: an integrated approach for health and environment. Proceedings of the International Meeting on Health \& Environment: Challenges for the Future, Roma Istituto Superiore di Sanità; (Rapporto ISTISAN, 09/12) 2009.

25. Europe. Commission regulation (EC) 19 December 2006, n. 1881. Setting maximum levels for certain contaminants in foodstuffs.

26. Food and Agricolture Organization of United Nations (FAO) and World Health Organization (WHO). Recommended International Code of Practice-General Principles of Food Hygiene 1997.

27. Food and Agricolture Organization of United Nations (FAO) and World Health Organization (WHO). FAO Code of Hygienic Practice for Fresh Fruits and Vegetables 2003.

28. Food and Drug Administration (FDA). Guidance for Industry: Guide to Minimize Microbial Food Safety Hazards of Leafy Greens; Draft Guidance. 2009. Available from: http://www.fda.gov/Food/GuidanceComplianceRegulatoryI nformation/GuidanceDocuments/ProduceandPlanProducts/ ucm 174200.htm.

29. Gómez-López VM, Devlieghere F, Ragaert P, Debevere J. Shelf-life extension of minimally processed carrots by gaseous chlorine dioxide. Int J Food Microbiol 2007;116:221-7. http://dx.doi.org/10.1016/j.ijfoodmicro.2006.12.008

30. Gil MI, Selma MV, López-Gálvez F, Allende A. Fresh-cut product sanitation and wash water disinfection: Problems and solutions. Int J Food Microbiol 2009;134:37-45. http://dx.doi.org/10.1016/j.ijfoodmicro.2009.05.021

31. Allende A, Selma MV, López-Gálvez F, Villaescusa R, Gil MI. Role of commercial sanitizers and washing systems on epiphytic microorganisms and sensory quality of fresh-cut escarole and lettuce. Postharvest Biol Technol 2008;49:155-63. http://dx.doi.org/10.1016/j.postharvbio.2007.12.010

32. Beltrán D, Selma MV, Tudela JA, Gil MI. Effect of different sanitizers on microbial and sensory quality of fresh-cut potato strips stored under modified atmosphere or vacuum packaging. Postharvest Biol Technol 2005;37:37-46.

33. Francis GA, O'Beirne D. Effect of vegetable type and antimicrobial dipping on survival and growth of Listeria innocua and Eschericha coli. Int J Food Sci Technol 2002;37:711-8. http://dx.doi.org/10.1046/j.1365-2621.2002.00622.x

34. Gonzalez RJ, Luo Y, Ruiz-Cruz S, McEvoy JL. Efficacy of sanitizers to inactivate Escherichia coli $\mathrm{O} 157: \mathrm{H} 7$ on freshcut carrot shreds under simulated process water conditions. J Food Prot 2004;67:2375-80.

35. Park WP, Lee DS. Effect of chlorine treatment on cut water cress and onion. J Food Qual 1995;18:415-24. http://dx.doi.org/10.1111/j.1745-4557.1995.tb00391.x

36. De Giusti M, Aurigemma C, Marinelli L, Tufi D, De Medici D, Di Pasquale S, De Vito C, Boccia A. The evaluation of the microbial safety of fresh ready-to-eat vegetables produced by different technologies in Italy. J Appl Microbiol 2010;109:996-1006. http://dx.doi.org/10.1111/j.1365-2672.2010.04727.x

37. Committee on toxicity of chemicals in food, consumer products and the environment 2007. Available from: http://cot. food.gov.uk/pdfs/cotstatementwashaids200614.pdf.

38. Abadias M, Usall J, Oliveira M, Alegre I, Viñas I. Efficacy of neutral electrolyzed water (NEW) for reducing microbial contamination on minimally-processed vegetables International. Int J Food Microbiol 2008:123:151-8. http://dx.doi.org/10.1016/j.ijfoodmicro.2007.12.008

39. Gutierrez J, Bourke P, Lonchamp J, Barry-Ryan C. Impact of plant essential oils on microbiological, organoleptic and quality markers of minimally processed vegetables. Innovative Food Sci Emerging Technol 2009;10(2):195-202. http://dx.doi.org/10.1016/j.ifset.2008.10.005

40. Kirby RM, Bartram J, Carr R. Water in food production and processing: quantity and quality concerns. Food Control 2003; 14:283-99.

41. Kim H, Bang J, Beuchat LR, Ryu JH. Synergistic effect of chlorine dioxide and drying treatments for inactivating Escherichia coli O157:H7 on radish seeds. J Food Prot 2010;73(7):1225-30.

42. Matsufuji H, Furukawa S, Teranishi K, Kawaharada K, Chino M, Yamagata K, Ogihara H, Yamasaki M. Effects of nonthermal processes on the inactivation of microorganisms and antioxidants in minimally processed vegetables. Food Sci Technol Res 2009;15(2):153-62. http://dx.doi.org/10.3136/fstr.15.153

43. Ölmez H, Kretzschmar U. Potential alternative disinfection methods for organic fresh-cut industry for minimizing water consumption and environmental impact. LWT - Food Sci Technol 2009;42:686-93.

44. Randazzo C, Pitino I, Scifo G, Caggia C. Biopreservation of minimally processed iceberg lettuces using a bacteriocin produced by Lactococcus lactis wild strain. Food Control 2009;20(8):756-63. http://dx.doi.org/10.1016/j.foodcont.2008.09.020

45. Vandekinderen I, Van Camp J, Devlieghere F, Ragaert P, Veramme K, Bernaert N, Denon Q, De Meulenaer B. Evaluation of the use of decontamination agents during fresh-cut leek processing and quantification of their effect on its total quality by means of a multidisciplinary approach. Innovative Food Sci Emerging Technol 2009;10:363-73. http://dx.doi.org/10.1016/j.ifset.2009.02.002

46. Zhang G, Ma L, Beuchat LR, Erickson M, Phelan VH, Doyle MP. Evaluation of treatments of elimination of foodborne pathogens on the surface of leaves and roots of lettuce (Lactuca sativa L. ). J Food Prot 2009;72(2):228-34.

47. Hassenberg K, Idler C. Influence of washing method on the quality of prepacked iceberg lettuce. Postdam (Germany): Agricultural Engineering International; 2005; p. 8.

48. Suslow TV. Postharvest chlorination. Basic properties and key points for effective disinfection. Regents of the University of California; 1997. (Publication 8003). 
49. Suslow TV. Water disinfection: a practical approach to calculating dose values for preharvest and postharvest applications. University of California. Agriculture and Natural Resources; 2001. (Publication 7256). Available from: http://vric.ucdavis.edu.

50. Varzakas T. Arvanitoyannis IS. Application of ISO22000 and comparison to HACCP for processing of ready to eat vegetables: Part I. Int J Food Sci Technol 2008;43:1729-41. http://dx.doi.org/10.1111/j.1365-2621.2007.01675.x

51. World Health Organization (WHO). Safe piped water: Managing microbial water quality in piped distribution systems. IWA Publishing; 2004.

52. American Public Health Association (APHA), American Water Works Association (AWWA), Water Environment Federation
(WEF). Standard methods for the examination of water and wastewater. Washington DC; 1992.

53. Italia. Decreto Legislativo 152/2006. Disposizioni sulla tutela delle acque dall'inquinamento e recepimento della direttiva 91/271/CEE concernente il trattamento delle acque reflue urbane e della direttiva 91/676/CEE relativa alla protezione delle acque dall'inquinamento provocato dai nitrati provenienti da fonti agricole. Gazzetta Ufficiale n. 88, 14 aprile 2006.

54. Italia. Decreto Ministeriale 185/2003. Regolamento recante norme tecniche per il riutilizzo delle acque reflue in attuazione dell'articolo 26, comma 2, del DL.gs. 11 maggio 1999, n. 152.

55. Europe. Council Directive 98/83/EC of 3 November 1998 on the quality of water intended for human consumption. 